\section{ASSESSMENT ON BIOACTIVE COMPOUNDS AND THE EFFECT OF MICROWAVE ON PITAYA PEEL}

\author{
Norashikin Mat Zain*, Muhd Azlan Nazeri, Nurul Aini Azman \\ Faculty of Chemical Engineering and Natural Resources, University \\ Malaysia Pahang, 26300, Gambang, Pahang, Malaysia
}

Article history

Received

31 May 2018

Received in revised form

12 October 2018

Accepted

1 November 2018

Published online

18 February 2019

\section{*Corresponding author} shikin@ump.edu.my

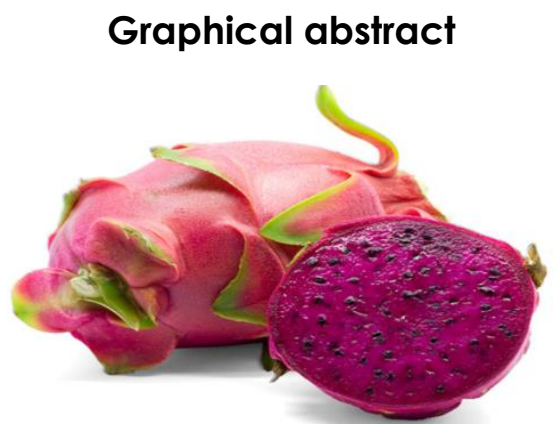

\begin{abstract}
Over the years, a wide variety of natural colour sources have been identified. One source, the pitaya fruit is known to impart colours to products, such as food and drink. However, there have been limited studies done to determine phenolic compounds and antibacterial activity of the pitaya peel (H.polyrhizus) via Microwave Assisted Extraction (MAE) method. Both this information can escalate the potential role of pitaya fruit as a natural colour source. This study aimed to identify the types of bioactive compounds (phenolic compounds) and antibacterial activity of pitaya peel. To achieve this objective, MAE was used to extract bioactive compounds from the pitaya peel as it maintained the integrity of the compound. Based on the results, 13 types of phenolic compounds were identified from the pitaya peel extract via qualitative research using library database matching which include quinic acid, cinnamic acid, quinic acid isomer, 3,4-dihydroxyvinylbenzene, isorhamnetin 3-O-rutinoside, myricetin rhamnohexoside, 3,30-di-O-methyl ellagic acid, isorhamnetin aglycone monomer, apigenin, jasmonic acid, oxooctadecanoic acid, 2 (3,4-dihydroxyphenyl)-7hydroxy-5-benzene propanoic acid and protocatechuic hexoside conjugate. The pitaya peel extract was also found to have small antibacterial effect on the Gram-positive, Staphylococcus aureus (S.aureus) and Gram- negative, Escherichia coli (E.coli). The SEM demonstrated that cell wall disruption of pitaya peel caused by microwave radiation from MAE appeared to be the main reason for rapid extraction of bioactive compounds. In conclusion, the study established that pitaya peel extract is a natural colour source with an abundance of phenolic compounds and minimal antibacterial activity, which could be used in the food and cosmetic industries.
\end{abstract}

Keywords: Microwave assisted extraction (MAE), pitaya peel, pitaya extract, phenolic compound, time-kill kinetics
Abstrak
Sepanjang tahun, banyak sumber warna semula jadi telah ditemui. Salah satu sumber adalah buah pitaya yang boleh menyumbang kepada warna untuk produk seperti makanan dan minuman. Bagaimanapun, kajian yang dilakukan terhad untuk menentukan sebatian fenolik dan aktiviti antibakterial daripada kulit pitaya (H.polyrhizus) melalui kaedah pengekstrakan berketuhar (MAE). Kedua-dua maklumat ini berkaitan dengan sebatian fenolik dan kesan antibakteria yang boleh meningkatkan peranan berpotensi buah pitaya sebagai sumber warna semulajadi. Oleh itu, kajian in telah dijalankan bertujuan untuk mengenal pasti sebatian bioaktif (sebatian fenolik) dan aktiviti antibakterial dari kulit pitaya. Untuk mencapai objektif ini, MAE telah digunakan untuk proses pengasingan sebatian 
bioaktif daripada kulit pitaya disebabkan ia dapat mengekalkan integriti sebatian. Berdasarkan keputusan, 13 jenis sebatian fenolik telah dikenalpasti melalui padanan yang bagus dengan pangkalan pada spectrometer jisim secara kualitatif termasuklah quinic acid, cinnamic acid, quinic acid isomer, 3,4dihydroxyvinylbenzene, isorhamnetin 3-O-rutinoside, myricetin rhamno-hexoside, 3,30-di-O-methyl ellagic acid, isorhamnetin aglycone monomer, apigenin, jasmonic acid, oxooctadecanoic acid, 2 (3,4-dihydroxyphenyl)-7-hydroxy-5benzene propanoic acid and protocatechuic hexoside conjugate. Sementara itu, buah pitaya menunjukkan kesan kecil terhadap Gram-positive, Staphylococcus aureus (S.aureus) dan Gram- negative, Escherichia coli (E.coli). Selain itu, SEM menunjukkan bahawa kemusnahan dinding sel kulit pitaya yang disebabkan oleh radiasi gelombang mikro dari MAE adalah punca utama untuk pengekstrakan yang lebih cepat bagi sebatian bioaktif. Sebagai kesimpulan, kajian ini telah membuktikan potensi kulit pitaya ekstrak sebagai pewarna semula jadi kerana mengandungi sebatian fenolik yang banyak dan sifat minimal antibakterial, yang boleh digunakan dalam industri makanan dan kecantikan.

Kata kunci: Pengekstrakan berketuhar (MAE), kulit pitaya, ekstrak pitaya, sebatian fenolik, asai masa perencatan kinetik

(c) 2019 Penerbit UTM Press. All rights reserved

\subsection{INTRODUCTION}

Colouring has been widely used in food and cosmetic industries to make the products more appealing and attractive. As the public become increasingly concerned about the detrimental effects of synthetic colour additives on human health and environment, there has been an increase in demand for natural colour sources. Over the years, many natural sources for product colouring have been found, one of which is pitaya fruit.

Pitaya fruit is known to contain high phenolic compounds. Phenolic compounds are secondary metabolites produced in plants. They are found mostly in fruits, vegetables, herbs, roots, leaves and seeds. As partial response to the ecological and physiological pressures, phenolic compounds are synthesized by plants [1]. These compounds are considered as natural defense substances, either for reproduction or as sensorial properties including colour, bitterness, taste, astringency and flavour. The concentration of phenolic compounds in each plant may be influenced by physiological and geographic variations, environmental conditions, and genetic factors [2, 3]. In addition, phenolic compounds have been extensively exploited due to their natural biological activities against the bacteria, carcinogens, oxidation and aging process [4]. Natural sources, such as plants and fruits have been discovered to be antibacterial, leading to numerous investigations on the potential role of plant and fruit extracts as antibacterial agents. [5]. Similarly, the byproducts of plants were found to demonstrate the ability to kill bacteria [6].

Furthermore, previous studies reported that the concentration of phenolic compounds were higher in the peel than in the flesh of plants [7]. Despite this finding, agro-industrial residues, such as fruit peel remained unpopular among manufacturers. The fruit peel, generated in massive amounts from the fruit juice processing industry is normally discarded as waste material. To make the matter worse, these discarded peels often become environmental hazards which cause water pollution. [8]. The seemingly useless fruit peels could potentially be used as a source of phenolic compounds while reducing environmental pollution.

Currently, investigations of bioactive compounds of fruit peel are still lacking due to their low popularity and limited commercial application [9]. In fact, the specific bioactive compounds of fruit peels have never been reported [10]. Thus, the main objective of this study was to determine the bioactive compounds (phenolic compounds) and the antibacterial properties of fruit peels.

Pitaya fruits were chosen for this study because they contain rich polyphenols which are found to display antioxidant, antiproliferative and antibacterial activities [11]. There are three types of pitaya: Hylocereus undatus, red skin with white flesh; Hylocereus polyrhizus, red skin with red flesh and Selinecereus megalanthus, yellow skin with white flesh [12]. Hylocereus polyrhizus was selected for the experiment as it is known to contain higher phenolic compounds and antioxidant activity compared to the other pitaya species. In this study, the peel of pitaya fruits were used because $33 \%$ of the weight comes from their peel, which indicates the abundance of bioactive compounds present within the peel [13]. Besides, the fruit peel has several advantages, such as being inexpensive, can be found in abundance, and is a sustainable resource $[14,15]$. In addition, the peel and pulp contain natural colorants namely betacyanins (red pigment) and betaxanthin (yellow pigment) [13]. 
To isolate the different types of bioactive compounds from the plants, extraction process was important. Qualitative and quantitative studies of bioactive compounds from plant materials mostly relied on the selection of a proper extraction method [16]. Methods such as solvent-based extraction and cold pressing had drawbacks including safety hazards, high energy input, low product quality, low extraction yields, long extraction time, and environment risk. Therefore, MAE was applied in this research using sample preparation techniques because it could extract bioactive compounds more rapidly and provide better recovery than the conventional extraction process [17]. In this research, MAE was employed to prepare the samples due to its ability in extracting the bioactive compounds in a rapid manner, aside from limiting the degradation of bioactive compounds. It is also feasible in extracting phenolic compounds with higher yield compared to other conventional methods, such as soxhlet. In addition, the effect of cell wall disruption in the sample due to microwave radiation from MAE can be observed via scanning electron microscopy (SEM). The use of MAE could be further justified by its environmentally friendly feature which reduced the use of organic solvents during the extraction process[18].

To obtain a higher yield of bioactive compounds via MAE, water was used as the solvent extraction in this study. This was because studies have shown a higher extraction yield with the use of water compared to ethanol and methanol. This finding was also reported by Michel et al. [19] whereby water increased the contact surface area between the plant matrix and solvent, resulting in a higher extraction yield. Besides, water is known to have high dielectric properties constant which allowed more absorption and conversion of microwave energy from MAE into the heat to facilitate partition analytes from the sample into the solvent [20]. Moreover, the non-toxicity, non-corrosiveness, non-flammability, and cost-effectiveness of water made it the greenest solvent available [13].

Following the extraction and determination of the phenolic compounds in pitaya peel, antibacterial properties of the pitaya peel extract were determined. To evaluate in vitro antibacterial activity of an extract or a pure compound, a variety of laboratory methods could be used. The most known and basic method is optical density study also known as the time kill kinetic test [21]. This test was therefore used in this study to examine the antibacterial activity of peel extract. Additionally, the microscopic structural changes of pitaya peel before and after extraction was observed to understand the characteristic of MAE methods.

In essence, this study is the first to report the phenolic compounds and antibacterial activity from the extraction of $\mathrm{H}$. Polyrhizus using MAE and time-kill kinetics test. The findings from this study could serve as a starting point for more elaborate research on the potential use of agro-industrial residues as natural sources for various industries. Such endeavour would be essential in meeting the growing demand for natural products and more importantly, in conserving the environment.

\subsection{METHODOLOGY}

\subsection{Sample Collection}

The pitaya peel from $H$. polyrhizus were obtained from a supermarket in Temerloh, Pahang. The peels were weighed and washed with distilled water. Subsequently, the peels were cut into $2 \mathrm{~cm}$ portions. As part of the freeze-drying process, the samples were first frozen overnight in the fridge freezer at a temperature of $-80^{\circ} \mathrm{C}$ and then placed in the freeze dryer for 96 hours. Next, the freeze-dried samples were grounded and sifted through a 20 mesh $(0.85 \mathrm{~mm})$ sieve to produce the powdered samples. These samples were stored in bags and kept in a dry environment prior to conducting the experiment [22].

\subsection{Microwave-assisted Extraction (MAE)}

Extraction of the bioactive compounds from the pitaya peels was carried out using the MAE approach with the one-factor-at-a-time method (OFAT). The liquid-solid extraction was conducted by adding the freeze-dried samples and $50 \mathrm{~mL}$ of distilled water into a $1000 \mathrm{~mL}$ extraction vessel. Subsequently, the extraction vessel was placed into MAE. The best conditions of MAE, particularly power, temperature, time, and weight of the sample were applied which are 400W, 45, $20 \mathrm{~min}$ and $1.2 \mathrm{~g}$ respectively. Immediately after the extraction process, the homogenate was centrifuged at 9000 rpm for 40 minutes at $25^{\circ} \mathrm{C}$. After the centrifugation, the supernatant was collected and the same procedure was repeated twice to ensure maximum extraction of the bioactive compounds. All experiments were performed in triplicates $[23,24]$.

\subsection{Analysis of Solution Extraction}

\subsubsection{Determination of Phenolic Compounds by UHPLC-ESI-QTRAP-MSMS}

The supernatant obtained from the MAE was collected and filtered using the Whatman filter paper (size 5C). Next, the filtered solution was diluted with $5 \mathrm{~mL}$ of methanol (50\%) UHPLC grade and filtered with $0.45 \mu \mathrm{m}$ nylon syringe filter to inject a volume of $20 \mu \mathrm{L}$ into LCMSMS [25]. The analysis was performed using a Flexar FX 15 ultra-highperformance liquid chromatograph (UHPLC, PerkinElmer, Inc, Massachusetts, USA) coupled with an AB SCIEX 3200 QTrap hybrid linear ion trap triple quadruple mass spectrometer (equipped with a turbo ion spray source). 
The chromatographic separation was achieved on a Phenomenex Synergi Fusion $(100 \mathrm{~mm} \times 2.1 \mathrm{~mm} \times 3$ $\mu \mathrm{m})$ column. Mobile phase A contained water with $0.1 \%(\mathrm{v} / \mathrm{v})$ formic acid and $5 \mathrm{mM}$ ammonium format, while mobile phase $\mathrm{B}$ was composed of acetonitrile containing $5 \mathrm{mM}$ ammonium format. Elution was performed by means of a linear gradient from $5-95 \%$ B (0.01-10 minutes) held for 2 minutes, then returned to $10 \% \mathrm{~B}$ in 0.1 minutes, and finally re-equilibrated for 3 minutes before the next injection. Ionisation was achieved through electrospray ionisation on the $A B$ Sciex Turbo $\mathrm{V}$ source, at a temperature of $500^{\circ} \mathrm{C}$ using purified nitrogen gas (99\%) as the collision gas via nebulisation. Collision energy was set at $35 \mathrm{eV}$ for mass fragmentation purpose. A full scan with MS/MS data collection analysis was performed in a negative mode. Data analysis, processing and interpretation were carried out using the AB SCIEX Analyst 1.5 and Advance Chemistry Development, Inc (ACD/Labs, Ontario, Canada) MS Processor software. A Marker View Software (AB SCIEX, Massachusetts, USA) was used for the principal component analysis (PCA). The following parameters were used for PCA: retention time ( $R_{T}$ ) range: 0-15 minutes, tolerance: 0.5 minutes, mass range: $\mathrm{m} / \mathrm{z}$ 100-1000, mass tolerance: $0.01 \mathrm{Da}$ and noise threshold: 5. [26]

\subsubsection{Antibacterial Testing}

\subsubsection{Preparation of Medium}

\section{Preparation of Broth}

$500 \mathrm{~mL}$ of broth was divided and placed into 2 conical flasks, each containing $250 \mathrm{~mL}$ of broth. $15 \mathrm{~g}$ of Tryptone Soya Broth (TSB) was added to $500 \mathrm{~mL}$ of distilled water and transferred to the Schott bottle. The solution was stirred using the magnetic stirrer and boiled on a hotplate to dissolve completely. Each flask was filled with $100 \mathrm{~mL}$ of broth and sterilized in the autoclave at a temperature of $121^{\circ} \mathrm{C}$ for 20 minutes [27] .

\section{Preparation of Agar}

$20 \mathrm{~g}$ of Tryptone Soya Agar (TSA) was added to 500 $\mathrm{mL}$ of distilled water and transferred into the Schott bottle. The mixed solution was boiled on a hotplate to dissolve completely. Petri dishes, TSB and TSA were put into the autoclave at a temperature of $121^{\circ} \mathrm{C}$ for 15 minutes. The cap of the Schott bottles was made loose to withstand the high pressure. Meanwhile, the laminar flow cabinet was sprayed and wiped with $70 \%$ ethanol. Then, UV rays were turned on for 15 minutes to sterilize the workspace. After the autoclave cooled down, the agar medium was poured onto the petri dishes and left to harden. Once hardened, the petri dishes containing the agar medium were sealed with parafilm to prevent any contamination. Subsequently, the petri dishes were stored upside down in the freeze[28].

\subsubsection{Bacteria Culture Preparation}

Inoculum

S.aureus and E.coli were used as the test organisms, which were prepared from fresh colonies on TSA. One loopful of each of the bacteria was inoculated in different conical flasks containing $100 \mathrm{~mL}$ of TSB. The flasks were incubated in an incubator shaker at a temperature of $30{ }^{\circ} \mathrm{C}$ and at $150 \mathrm{rpm}$ for 18 hours until the exponential phase. Following the incubation, $100 \mu \mathrm{L}$ of each bacteria culture were reinoculated into new sterilized conical flasks containing $100 \mathrm{~mL}$ of TSB for another 22 hours to achieve $10^{8} \mathrm{CFU} / \mathrm{mL}$ [29].

\subsubsection{Analysis of Antibacterial}

Time-kill Kinetics Test

Time-kill kinetics test was the most appropriate method to reveal a time-dependent or a concentration-dependent antibacterial effect [30]. It was performed on the broth culture medium (TSB) using three conical flasks containing a bacterial suspension of S.aureus and E.coli, respectively. $50 \mathrm{~mL}$ of sterilized TSB were measured and placed into a conical flask. Three flasks were prepared for each bacteria suspension against the extracted sample. $1000 \mu \mathrm{L}$ of bacterial suspension were added into each flask. Following that, $5 \mathrm{~mL}$ and $10 \mathrm{~mL}$ of pitaya peel extract were added into the first and second conical flasks of TSB respectively. The third flask was prepared by excluding the pitaya peel extract and was considered as a growth control. To obtain the initial optical density (OD), the samples were taken immediately after addition of the pitaya peel extract. Subsequently samples were taken every twohourly up to a total of 14 hours $(2,4,6,8,10,12$ and 14 hours) with the incubation being done under a suitable condition $\left(30^{\circ} \mathrm{C}\right.$ and $\left.150 \mathrm{rpm}\right)$ [21]. For OD reading, the samples were also diluted to an appropriate concentration at a time interval of 2 hours. After that, the absorbance of the sample was measured with a spectrophotometer at $600 \mathrm{~nm}$ [31]. A calibration curve to relate the absorbance with the incubation time was then generated.

\subsection{Scanning Electron Microscopy (SEM) Observation}

The SEM (FET QUANTA-450, Netherlands) was employed to observe the morphological changes of pitaya peel samples before and after MAE extraction. The samples were oven-dried at $60^{\circ} \mathrm{C}$ for 15 minutes and sputtered with a thin layer of platinum. Next, the samples were observed under vacuum at an accelerating voltage of $8.0 \mathrm{KV}$ and 500 magnification [32]. 


\subsection{RESULTS AND DISCUSSION}

\subsection{Identification Phenolic Compounds}

Table 1 shows a total of 13 phenolic compounds found in the pitaya peel extract. Besides that, 28 compounds were classified as unknown compounds because of poor match with library database and were suspected as flavonoids compounds. The compounds were identified based on library database matching and their mass fragmentation pattern showed fingerprint for each compound [26]. Based on the full chromatogram from UHPLC-ESIQTRAP-MSMS analysis as presented in Figure 1, pitaya peel extract contained rich amounts of phenolic acid and flavonoids compounds. The analysis revealed that pitaya peel extract contained quinic acid, cinnamic acid, quinic acid isomer, 3,4dihydroxyvinylbenzene, isorhamnetin 3-O-rutinoside, myricetin rhamno-hexoside, 3,30-di-O-methyl ellagic acid, isorhamnetin aglycone monomer, apigenin, jasmonic acid, oxooctadecanoic acid, 2 (3,4dihydroxyphenyl)-7-hydroxy-5-benzene propanoic acid and protocatechuic hexoside conjugate.

Although phenolic contents of H.polyrhizus had previously been studied, there were no full scan studies of the phenolic compounds [10]. This study is therefore the first to have identified specific bioactive compounds in pitaya peel extract of H.polyrhizus via MAE. Based on the results, the analysis of the pitaya peel extract with UHPLC revealed two types of phenolic acids, which were hydroxycinnamic acids (quinic acid, cinnamic acid, quinic acid isomer and 2 (3,4-dihydroxyphenyl)-7-hydroxy-5-benzene propanoic acid) and hydroxybenzoic acids (3,4dihydroxy vinylbenzene, 3,30-di-O-methyl ellagic acid and protocatechuic hexoside conjugate). Hydroxybenzoic acids had a C6-Cl chemical structure whereas hydroxycinnamic acids had a C6C3 structure with a double bond in the side chain in cis or trans configuration [33]. The remaining compounds identified from the pitaya peel extract were flavonoids, which displayed antioxidant [11, 3436], antiproliferative [37] and antibacterial activities [11]. The flavonoids identified in this study are isohamnetin-3-o-rutinoside, isorhamentin aglycone monomer, jasmonic acid, apigenin and myricetin rhamno-hexoside.
Table 1 Compounds identified in pitaya peel extracted based on UHPLC-ESI-QTRAP-MSMS

\begin{tabular}{|c|c|c|c|}
\hline $\begin{array}{l}\text { Retention } \\
\text { time (min) }\end{array}$ & {$[\mathrm{M}-\mathrm{H}]^{-}$} & $\begin{array}{l}\text { Mass fragment, } \\
\text { MS/MS (m/z) }\end{array}$ & $\begin{array}{l}\text { Compound } \\
\text { identified }\end{array}$ \\
\hline 1.424 & 191.40 & $\begin{array}{l}191.05,172.92, \\
110.98\end{array}$ & Quinic acid \\
\hline 1.986 & 147 & $\begin{array}{l}56.90,86.95 \\
102.97\end{array}$ & Cinnamic acid \\
\hline 3.866 & 191.20 & $\begin{array}{l}191.04,172.99 \\
110.93\end{array}$ & Quinic acid isomer \\
\hline 3.977 & 135.19 & $\begin{array}{l}135.00,116.88 \\
88.80\end{array}$ & $\begin{array}{l}\text { 3,4-Dihydroxy } \\
\text { vinylbenzene }\end{array}$ \\
\hline 4.033 & 623.20 & $\begin{array}{l}623.14,605.25, \\
579.00,314.04, \\
299.04\end{array}$ & $\begin{array}{l}\text { Isorhamnetin 3-O- } \\
\text { rutinoside }\end{array}$ \\
\hline 5.037 & 625.32 & $\begin{array}{l}625.14,315.10 \\
300.20\end{array}$ & $\begin{array}{l}\text { Myricetin rhamno- } \\
\text { hexoside }\end{array}$ \\
\hline 6.154 & 328.78 & $\begin{array}{l}329.30,311.29, \\
229.21,211.16, \\
171.15,139.14\end{array}$ & $\begin{array}{l}\text { 3,30-di-O-methyl } \\
\text { ellagic acid }\end{array}$ \\
\hline 6.489 & 314.80 & $\begin{array}{l}315.12,300.08 \\
271.06,243.12 \\
164.04\end{array}$ & $\begin{array}{l}\text { Isorhamnetin } \\
\text { aglycone monomer }\end{array}$ \\
\hline 6.600 & 269.13 & $\begin{array}{l}269.15,251.10 \\
225.29,197.04\end{array}$ & Apigenin \\
\hline 7.045 & 209.22 & $209.12,163.15$ & Jasmonic acid \\
\hline 7.489 & 297.35 & $297.23,183.00$ & $\begin{array}{l}\text { Oxooctadecanoic } \\
\text { acid }\end{array}$ \\
\hline 8.043 & 310.40 & $\begin{array}{l}311.20,183.03 \\
96.91\end{array}$ & $\begin{array}{l}2 \text { (3,4- } \\
\text { Dihydroxyphenyl)-7- } \\
\text { hydroxy-5-benzene } \\
\text { propanoic acid }\end{array}$ \\
\hline 8.600 & 595.40 & $\begin{array}{l}595.24,315.03 \\
279.28,241.04\end{array}$ & $\begin{array}{l}\text { Protocatechuic } \\
\text { Hexoside conjugate }\end{array}$ \\
\hline
\end{tabular}

The findings in Table 1 differed from the findings reported by Lourith and Kanlayavattanakul [10] where chlorogenic acid, gallic acid and quercetin were identified from pitaya peel extract via HPLC (Waters 2695, Agilent, USA). The different findings are due to using different type of HPLC in phenolic compounds identification, which in this study used more advance HPLC. Nevertheless, the results of this research are consistent with the findings of previous work which similarly extracted phenolic compounds from other fruits and plants via MAE [20]. This indicates that MAE is an efficient method which could be used to extract different type of phenolic compounds. Additionally, Fang et al. [38] revealed that a lower consumption of solvent in MAE would give rise to a higher yield of phenolic compounds. This study established a similar finding where the use of a lower amount of solvent in MAE provided stability to the phenolic compounds, allowing them to be identified from the samples. 


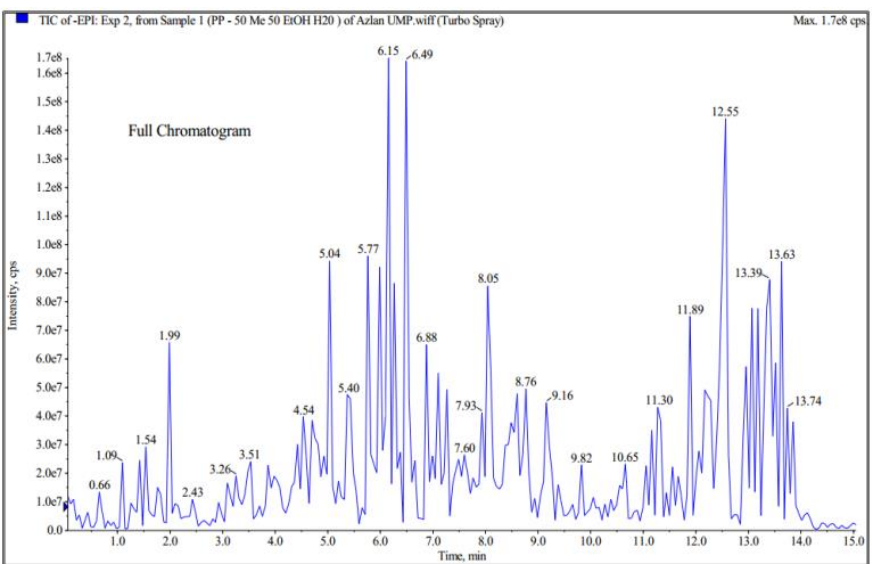

Figure 1 The UHPLC-ESI-QTRAP-MSMS (negative mode) of the extracts of pitaya peels

\subsection{Time-kill Kinetics Test of Pitaya Peel Extract}

Figures 2 and 3 show the optical density (OD) of the samples taken every 2-hourly up to 14 hours. In this study, time-kill kinetics was chosen because this method was faster, easy-to-use and flexible method.

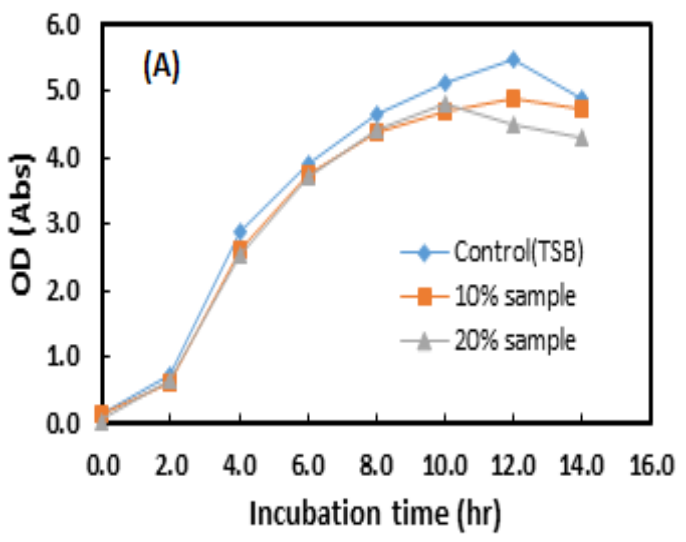

Figure 2 Growth curve of S. aureus at $37^{\circ} \mathrm{C}$ and $120 \mathrm{rpm}$

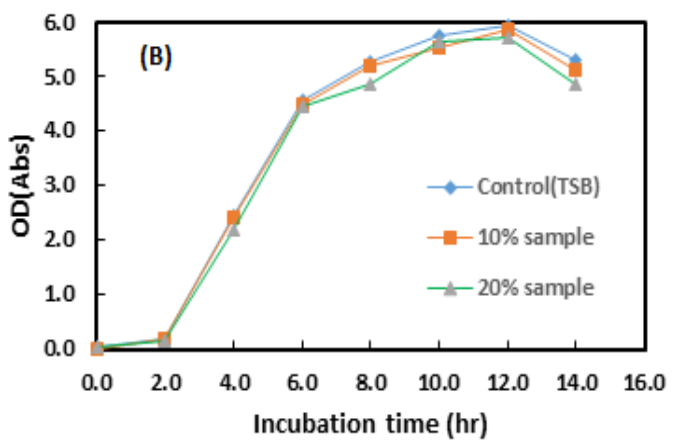

Figure 3 Growth curve of E. coli at $37^{\circ} \mathrm{C}$ and $120 \mathrm{rpm}$

The growth profile of the S.aureus and E.coli is shown in Figures 2 and 3 respectively. During the lag phase (0-2 hour), the growth of the S.aureus and
E.coli should theoretically decline after inoculation because the cells need time to adapt to the new environment inside the conical flask. The lag phase should occur immediately after inoculation as a period of adaptation of cell to a new environment $[40,41]$. During this phase, cell mass may increase a little without an increase in the cell number density. Nonetheless, the lag phase was not evident from the graph of this study. This finding could be due to the lag phase being too short to notice as a result of the two-hourly sample OD reading.

Furthermore, the length of the lag phase was known to be affected by the bacterial age and inoculum size. According to Swinnen et al. [41] the shortest lag phase and the time to the first division were obtained with the largest inoculum and the youngest inoculated parent cells. The decrease of inoculum size can be explained by the increased lag phase duration and the corresponding variation as reported by numerous researchers [42]. Thus, the short lag phase found in this experiment might be due to the age of the inoculated parent cells.

The exponential phase (log phase or growth phase) from the 2 nd to 6 th hour shown in Figures 2 and 3 indicate the full adaption of the cells to the new environment of the conical flask and therefore, their ability to grow and produce new cells [43]. Direct visual measurement of the different growth curve patterns was performed in this experiment. The values of the growth curve of S.aureus and E.coli for $10 \%$ and $20 \%$ pitaya peel extract were slightly lower than the control. The bioactive compounds in pitaya peel extract demonstrated an ability to inhibit S.aureus and E.coli growth even though the effect was small. The growth of the S.aureus and E.coli slowed down after the sixth hour.

Based on Figures 2 and 3, stationary phase of the growth profile started after $t=6$ hours until $t=12$ hours, while the death phase of the growth profile began after $t=12$ hours. It is unclear from this study whether inoculum size was a critical factor affecting the transition from the exponential phase to stationary phase. Hence, further studies would be needed to assess the effect of inoculum size on the late exponential and early stationary phase [42].

During the stationary phase, the death rate was equal to the growth rate of the cells. The growth of S.aureus and E.coli could be limited by nutrient depletion at the level where cell growth could not be sustained. During this phase, the growth curve of the control was expected to give a higher OD value than pitaya peel extract, with the $10 \%$ pitaya peel extract similarly giving a higher OD value than the $20 \%$ sample extracted. The result of the experiment between the $8^{\text {th }}$ hour and the $10^{\text {th }}$ hour however, did not show a trend as predicted. Instead, the $20 \%$ pitaya peel extract had a slightly higher OD value than that of the $10 \%$ sample extracted. This finding could be due to errors in reading the stationary phase of the growth profile graph. To avoid such errors, it is recommended that only two cuvettes be used, one for blank (fresh TSB) and the other for 
samples, throughout the experiment as different cuvettes might allow different amounts of light intensity to pass through.

On further examination of the graph, it was evident that the death phase began after 12 hours. The OD of the cells from the three growth curves decreased as the cells lysed and released their intracellular metabolites into the growth medium [44, 45]. Cells might undergo apoptosis (cell suicide) process during its death phase. Nutrient depletion often initiated the apoptosis process which involved DNA cleavage, after which the cells would shrink [46].

As can be seen, the OD value between samples and control were slightly close for each incubation period. The result obtained was consistent with previous work by Majhenič et al. [47]. Their study concluded that, by using boiling water as solvent, guarana (Paullinia cupana) seed extract had little yet sufficient antibacterial activity to be used in food products as antibacterial agents. Similar findings were observed in other studies where time-kill kinetics test was reported to be able to detect differences in the rate and extent of antibacterial and antifungal over time $[48,49]$.

\subsection{Analysis of Microscopic Changes}

Figure 4 (a) presents the untreated sample that displays an intact external structure with many folded layers. Most of the external structures in pitaya peel that were analyzed via MAE had become flat and completely ruptured, as shown in Figure 4 (b). This indicates that microstructural changes in the cell walls are caused by MAE [50].

The disruption of cell wall in pitaya peel extract due to microwave radiation can promote the release of greater amounts of bioactive compounds into the solvent extraction within a short time [51, 52]. The two transport patterns pertaining to mass and heat that function in the same direction (from the inside to the outside of pitaya peel) accelerate the rates of extraction in MAE [53, 54]. Additionally, microwave radiation increased the temperature rapidly for the sample, thus causing the cell wall to rupture and facilitate the rapid release of bioactive compounds. Hu et al. [32] asserted that the effects of both cavitation and turbulence generated by microwave radiation can also destroy cell wall and promote mass transfer simultaneously, thus increasing the extraction yield.

This result is similar to that recorded by Yanık [55], who applied MAE to extract bioactive compounds from oilive pomace. Hu et al. [32] also reported a similar pattern in extracting bioactive compounds from Tiger Nut (Cyperus esculentus L.), which demonstrated that cell wall disruption of the samples had been due to microwave radiation, as observed via SEM.

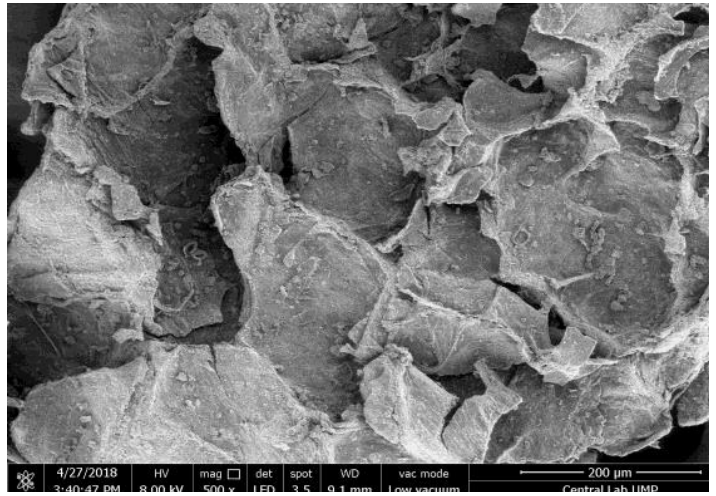

(a)

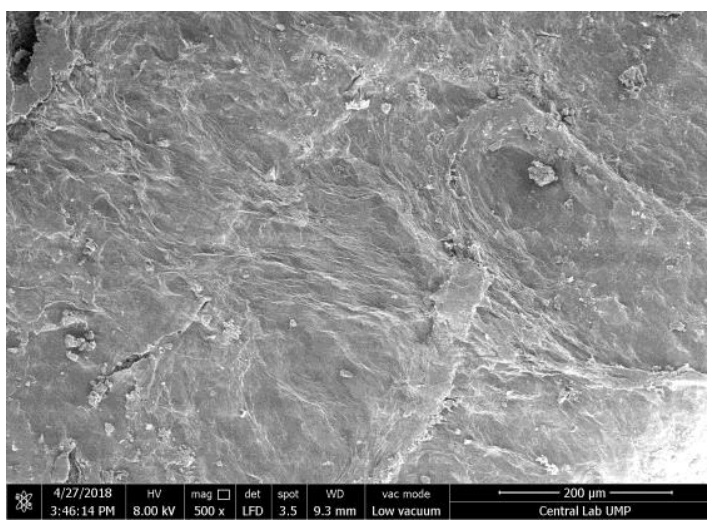

(b)

Figure 4 SEM of Pitaya Peel; (a) Pitaya Peel Without Treatment (500 x), and (b) Pitaya Peel By MAE (500 x)

\subsection{CONCLUSION}

As evidenced by the full chromatogram from UHPLCESI-QTRAP-MSMS analysis, pitaya peel solution extraction was found to be high in polyphenols and flavonoids compounds. Furthermore, MAE was the optional equipment for extraction of pitaya peel as it maintained the integrity of their bioactive compounds. Additionally, time-kill kinetics test was an efficient method to determine the level of antibacterial activity in pitaya peel extract. The pitaya peel extract was proven to have antibacterial properties as the extract demonstrated small effect of antibacterial activity against both S.aureus and E.coli. In conclusion, pitaya peel is a natural colour source which could be used in food and cosmetic products. Additionally, SEM demonstrated that structural disruption of pitaya peel caused by microwave radiation was the main reason for rapid exraction. So, MAE could be a good alternative for extraction of pitaya peel and other herbs. 


\section{Acknowledgment}

The authors would like to express their gratitude to University Malaysia Pahang for the financial support through grant RDU150312.

\section{References}

[1] Kennedy, D. O. and Wightman, E. L. 2011. Herbal Extracts and Phytochemicals: Plant Secondary Metabolites and The Enhancement of Human Brain Function. Advances in Nutrition: An International Review Journal. 2(1): 32-50.

[2] Figueiredo, A. C., Barroso, J. G., Pedro, L. G., and Scheffer J. J. 2008. Factors Affecting Secondary Metabolite Production in Plants: Volatile Components and Essential Oils. Flavour and Fragrance Journal. 23(4): 213-226.

[3] Norashikin, M. and Ibrahim, M. 2010. Fabrication and Characterization of Sawdust Composite Biodegradable Film. World Academy of Science, Engineering and Technology. 65: 864-868.

[4] Ham, S.-S., Kim, S.-H., Moon, S.-Y., Chung, M. J., Cui, C.-B. Han, E.-K., Chung, C.-K., and Choe, M. 2009. Antimutagenic Effects of Subfractions of Chaga Mushroom (Inonotus Obliquus) Extract. Mutation Research/Genetic Toxicology and Environmental Mutagenesis. 672(1): 55-59.

[5] Mabona, U., Viljoen, A., Shikanga, E., Marston, A., and Van Vuuren, S. 2013. Antimicrobial Activity of Southern African Medicinal Plants with Dermatological Relevance: From an Ethnopharmacological Screening Approach, to Combination Studies and the Isolation of a Bioactive Compound. Journal of Ethnopharmacology. 148(1): 45-55.

[6] Pereira, J. A., Oliveira, I., Sousa, A., Ferreira, I. C., Bento, A., and Estevinho, L. 2008. Bioactive Properties and Chemical Composition of Six Walnut (Juglans regia L.) Cultivars. Food and Chemical Toxicology. 46(6): 2103-2111.

[7] Fattouch, S., Caboni, P., Coroneo, V., Tuberoso, C., Angioni, A., Dessi, S., Marzouki, N., and Cabras, P. 2008. Comparative Analysis of Polyphenolic Profiles and Antioxidant and Antimicrobial Activities of Tunisian Pome Fruit Pulp and Peel Aqueous Acetone Extracts. Journal of Agricultural and Food Chemistry. 56(3): 1084-1090.

[8] Ismail, N. S. M., Ramli, N., Hani, N. M., and Meon, Z. 2012. Extraction and Characterization of Pectin from Dragon Fruit (Hylocereus polyrhizus) Using Various Extraction Conditions. (Pengekstrakan dan Pencirian Pektin Daripada Buah Naga (hylocereus polyrhizus) Menggunakan Pelbagai Keadaan Pengekstrakan). Sains Malaysiana. 41 (1): 41-45.

[9] Soong, Y.-Y. and Barlow, P. J. 2004. Antioxidant Activity and Phenolic Content of Selected Fruit Seeds. Food Chemistry. 88(3): 411-417.

[10] Lourith, N. and Kanlayavattanakul, M. 2013. Antioxidant and Stability of Dragon Fruit Peel Colour. Agro Food Ind HiTech. 24: 56-8.

[11] Tenore, G. C., Novellino, E., and Basile, A. 2012. Nutraceutical Potential and Antioxidant Benefits of Red Pitaya (Hylocereus polyrhizus) Extracts. Journal of Functional Foods. 4(1): 129-136.

[12] Grimaldo, O., Terrazas, T., García-Velásquez, A., CruzVillagas, M., and Ponce-Medina, J. F. 2007. Morphometric Analysis of 21 Pitahaya (Hylocereus undatus) Genotypes. Journal of the Professional Association for Cactus Development. 9: 99-117.

[13] Ferreres, F., Grosso, C., Gil-Izquierdo, A., Valentão, P., Mota, A. T., and Andrade, P. B. 2017. Optimization of the Recovery of High-value Compounds from Pitaya Fruit ByProducts Using Microwave-assisted Extraction. Food Chemistry. 230: 463-474.
[14] Vinardell, M., Ugartondo, V., and Mitjans, M. 2008. Potential Applications of Antioxidant Lignins from Different Sources. Industrial Crops and Products. 27(2): 220-223.

[15] Rodrigues, F., Palmeira-de-Oliveira, A., das Neves, J., Sarmento, B., Amaral, M. H., and Oliveira, M. B. 2013. Medicago spp. Extracts as Promising Ingredients for Skin Care Products. Industrial Crops and Products. 49: 634-644.

[16] Sasidharan, S., Chen, Y. Saravanan, D., Sundram, K., and Latha, L. Y. 2011 . Extraction, Isolation and Characterization of Bioactive Compounds from Plants' Extracts. African Journal of Traditional, Complementary and Alternative Medicines. 8(1).

[17] Azmir, J., Zaidul, I., Rahman, M., Sharif, K., Mohamed, A., Sahena, F., Jahurul, M., Ghafoor, K., Norulaini, N., and Omar, A. 2013. Techniques for Extraction of Bioactive Compounds from Plant Materials: A Review. Journal of Food Engineering. 117(4): 426-436.

[18] Rombaut, N., Tixier, A. S., Bily, A., and Chemat, F. 2014. Green Extraction Processes of Natural Products as Tools for Biorefinery. Biofuels, Bioproducts and Biorefining. 8(4): 530544.

[19] Michel, T., Destandau, E., and Elfakir, C. 2011. Evaluation of a Simple and Promising Method for Extraction of Antioxidants from Sea Buckthorn (Hippophaë rhamnoides L.) berries: Pressurised Solvent-free Microwave Assisted Extraction. Food Chemistry. 126(3): 1380-1386.

[20] Cong, X., Bing, W., Yi-Qiong, P., Jian-Sheng, T., and Tong, Z. 2017. Advances in Extraction and Analysis of Phenolic Compounds from Plant Materials. Chinese Journal of Natural Medicines. 15(10): 721-731.

[21] Balouiri, M., Sadiki, M., and Ibnsouda, S. K. 2016. Methods for in Vitro Evaluating Antimicrobial Activity: A Review. Journal of Pharmaceutical Analysis. 6(2): 71-79.

[22] Chaiwut, P., O-ki-la, A., Phuttisatien, I., Thitilertdecha, N., and Pintathong, P. 2012. Extraction and Stability of Cosmetic Bioactive Compounds. Paper Presented at the Mae Fah Luang University International Conference, School of Cosmetic Science, Mae Fah Luang University, Chiang Rai 57100, Thailand. retrieved from

[23] Nazeria, M. A. and Zainb, N. M. 2018. Effect of Different Operating Parameters on Extraction of Active Compounds from Pitaya Peel By Microwave Assisted Extraction (Mae). Jurnal Teknologl. 80(2): 51-58.

[24] Zain, N. and Nazeri, M. 2016. Antioxidant and Mineral Content of Pitaya Peel Extract Obtained Using Microwave Assisted Extraction (MAE). Australian Journal of Basic and Applied Sciences. 10(17): 63-68.

[25] Souza, Bataglion, G. A., da Silva, F. M., de Almeida, R. A. Paz, W. H., Nobre, T. A., Marinho, J. V., Salvador, M. J., Fidelis, C. H., and Acho, L. D. 2016. Phenolic and Aroma Compositions of Pitomba Fruit (Talisia esculenta Radlk.) assessed by LC-MS/MS and HS-SPME/GC-MS. Food Research International. 83: 87-94.

[26] Lau, B. F., Abdullah, N., Aminudin, N., Lee, H. B., Yap, K. C. and Sabaratnam, V. 2014. The Potential of Mycelium and Culture Broth of Lignosus rhinocerotis as Substitutes for the Naturally Occurring Sclerotium with Regard to Antioxidant Capacity, Cytotoxic Effect, and Low-Molecular-Weight Chemical Constituents. PloS one. 9(7): e102509.

[27] Park, S.-E., Ko, W.-K., Park, J. H., Bayome, M., Park, J., Heo, D. N., Lee, S. J., Moon, J.-H., Kwon, I. K., and Kook, Y.-A 2016. Antibacterial Effect of Silver and Gold Nanoparticle Coated Modified C-Palatal Plate. Journal of Nanoscience and Nanotechnology. 16(8): 8809-8813.

[28] Jayaprakash, N., Vijaya, J. J., Kaviyarasu, K., Kombaiah, K., Kennedy, L. J., Ramalingam, R. J., Munusamy, M. A., and Al-Lohedan, H. A. 2017. Green Synthesis of Ag Nanoparticles Using Tamarind Fruit Extract for the Antibacterial Studies. Journal of Photochemistry and Photobiology B: Biology. 169: 178-185.

[29] Hafsa, J., ali Smach, M., Khedher, M. R. B., Charfeddine, B., Limem, K., Majdoub, H., and Rouatbi, S. 2016. Physical, Antioxidant and Antimicrobial Properties of Chitosan Films 
Containing Eucalyptus Globulus Essential Oil. LWT-Food Science and Technology. 68: 356-364.

[30] Pfaller, M., Sheehan, D., and Rex, J. 2004. Determination of Fungicidal Activities Against Yeasts and Molds: Lessons Learned from Bactericidal Testing and the Need for Standardization. Clinical Microbiology Reviews. 17(2): 268280.

[31] Bernardez, L. and Andrade, L. 2015. Improved Method for Enumerating Sulfate-reducing Bacteria Using Optical Density. MethodsX. 2: 249-255.

[32] Hu, B., Zhou, K., Liu, Y., Liu, A., Zhang, Q., Han, G., Liu, S. Yang, Y., Zhu, Y., and Zhu, D. 2018. Optimization of Microwave-assisted Extraction of Oil from Tiger Nut (Cyperus esculentus L.) and its Quality Evaluation. Industrial Crops and Products. 115: 290-297. doi:https://doi.org/10.1016/j.indcrop.2018.02.034.

[33] Quifer, P., Vallverdú-Queralt, A., Martínez-Huélamo, M. Chiva-Blanch, G., Jáuregui, O., Estruch, R., and LamuelaRaventós, R. 2015. A Comprehensive Characterisation of Beer Polyphenols by High Resolution Mass Spectrometry (LC-ESI-LTQ-Orbitrap-MS). Food Chemistry. 169: 336-343.

[34] Esquivel, P., Stintzing, F. C., and Carle, R. 2007. Phenolic Compound Profiles and Their Corresponding Antioxidant Capacity of Purple Pitaya (Hylocereus sp.) genotypes. Zeitschrift für Naturforschung C. 62(9-10): 636-644.

[35] Kim, H., Choi, H. K., Moon, J. Y., Kim, Y. S., Mosaddik, A., and Cho, S. K. 2011. Comparative Antioxidant and Antiproliferative Activities of Red and White Pitayas and Their Correlation with Flavonoid and Polyphenol Content. Journal of Food Science. 76(1): C38-C45.

[36] Ramli, N. S., Ismail, P., and Rahmat, A. 2014. Influence of Conventional and Ultrasonic-assisted Extraction on Phenolic Contents, Betacyanin Contents, and Antioxidant Capacity of Red Dragon Fruit (Hylocereus polyrhizus). The Scientific World Journal. 2014.

[37] Kim, H., Choi, H. K., Moon, J. Y., Kim, Y. S., Mosaddik, A., and Cho, S. K. 2011. Comparative Antioxidant and Antiproliferative Activities of Red and White Pitayas and Their Correlation with Flavonoid and Polyphenol Content. Journal of Food Science. 76(1).

[38] Fang, X., Wang, J., Hao, J., Li, X., and Guo, N. 2015. Simultaneous Extraction, Identification and Quantification of Phenolic Compounds in Eclipta Prostrata Using Microwave-assisted Extraction Combined with HPLCDAD-ESI-MS/MS. Food Chemistry. 188: 527-536.

[39] Mertens, L., Van Derlinden, E., and Van Impe, J. F. 2012. A Novel Method for High-throughput Data Collection in Predictive Microbiology: Optical Density Monitoring of Colony Growth as a Function of Time. Food Microbiology. 32(1): 196-201.

[40] Métris, A., George, S., and Baranyi, J. 2006. Use of Optical Density Detection Times to Assess the Effect of Acetic Acid on Single-cell Kinetics. Applied and Environmental Microbiology. 72(10): 6674-6679.

[41] Swinnen, I., Bernaerts, K., Dens, E. J., Geeraerd, A. H., and Van Impe, J. 2004. Predictive Modelling of the Microbial Lag Phase: A Review. International Journal of Food Microbiology. 94(2): 137-159.
[42] Wang, Y. and Buchanan, R. L. 2016. Develop Mechanistic Models of Transition Periods between Lag/Exponential And Exponential/Stationary Phase. Procedia Food Science. 7: 163-167.

[43] Vargas, S., Millán-Chiu, B. E., Arvizu-Medrano, S. M., Loske, A. M., and Rodríguez, R. 2017. Dynamic Light Scattering: A Fast and Reliable Method to Analyze Bacterial Growth During the Lag Phase. Journal of Microbiological Methods. 137: 34-39.

[44] Bayles, K. W. 2014. Bacterial Programmed Cell Death: Making Sense of a Paradox. Nature Reviews Microbiology. 12(1): 63-69.

[45] Monds, R. D. and Toole, G. A. 2009. The Developmental Model of Microbial Biofilms: Ten Years of a Paradigm Up for Review. Trends in Microbiology. 17(2): 73-87.

[46] Peeters, S. H. and Jonge, M. I. 2017. For the Greater Good: Programmed Cell Death in Bacterial Communities. Microbiological Research. 207:161-169

[47] Majhenič, L., Škerget, M., and Knez, Ž. 2007. Antioxidant and Antimicrobial Activity of Guarana Seed Extracts. Food Chemistry. 104(3): 1258-1268.

[48] Guo, N., Ling, G., Liang, X., Jin, J., Fan, J., Qiu, J., Song, Y., Huang, N., Wu, X., and Wang, X. 2011. In Vitro Synergy of Pseudolaric Acid B and Fluconazole Against Clinical Isolates of Candida Albicans. Mycoses. 54(5).

[49] Mback, M. N., Agnaniet, H., Nguimatsia, F., Dongmo, P.-M. J., Fokou, J.-B. H., Bakarnga-Via, I., Boyom, F. F., and Menut, C. 2016. Optimization of Antifungal Activity of Aeollanthus Heliotropioides Oliv Essential Oil and Time Kill Kinetic Assay. Journal de Mycologie Médicale/Journal of Medical Mycology. 26(3): 233-243.

[50] Flórez, N., Conde, E., and Domínguez, H. 2015. Microwave Assisted Water Extraction of Plant Compounds. Journal of Chemical Technology and Biotechnology. 90(4): 590-607.

[51] Bail, S., Stuebiger, G., Krist, S., Unterweger, H., and Buchbauer, G. 2008. Characterisation of Various Grape Seed Oils by Volatile Compounds, Triacylglycerol Composition, Total Phenols and Antioxidant Capacity. Food Chemistry. 108(3): 1122-1132. doi:https://doi.org/10.1016/j.foodchem.2007.11.063

[52] Desai, M., Parikh, J., and Parikh, P. 2010. Extraction of Natural Products Using Microwaves as a Heat Source. Separation \& Purification Reviews. 39(1-2): 1-32.

[53] Virot, M., Tomao, V., Ginies, C., Visinoni, F., and Chemat, F. 2008. Microwave-integrated Extraction of Total Fats and Oils. Journal of Chromatography A. 1196: 57-64.

[54] Farhat, A., Fabiano-Tixier, A.-S., Maataoui, M. E., Maingonnat, J.-F., Romdhane, M., and Chemat, F. 2011. Microwave Steam Diffusion for Extraction of Essential Oil from Orange Peel: Kinetic Data, Extract's Global Yield and Mechanism. Food Chemistry. 125(1): 255-261. doi:https://doi.org/10.1016/j.foodchem.2010.07.110.

[55] Yanık, D. K. 2017. Alternative to Traditional Olive Pomace Oil Extraction Systems: Microwave-Assisted Solvent Extraction of Oil From Wet Olive Pomace. LWT-Food Science and Technology. 77: 45-51. 